\title{
USAGE OF PRODUCTION FUNCTIONS IN THE COMPARATIVE ANALYSIS OF TRANSPORT RELATED FUEL CONSUMPTION
}

\author{
Adam Torok ${ }^{1}$, Arpad Torok', Florian Heinitz ${ }^{3}$ \\ ${ }^{I}$ Budapest University of Technology and Economics \\ Departtment of Transport Economics, \\ H-1111, Budapest, Muegyetemrkp 3 \\ E-mail:atorok@kgazd.bme.hu \\ ${ }^{2}$ Budapest University of Technology and Economics \\ Departtment of Transport Economics, \\ H-1111, Budapest, Muegyetemrkp. 3 \\ E-mail:artorok@kgazd.bme.hu \\ ${ }^{3}$ Erfurt University of Applied Sciences, \\ InstitutVerkehr und Raum, \\ AltonaerStraße 25, D - 99085 Erfurt; Germany \\ E-mail: heinitz@fh-erfurt.de
}

\begin{abstract}
This contribution aims to examine the relationship between the transport sector and the macroeconomy, particularly in fossil energy use, capital and labour relations. The authors have investigated the transport related fossil fuel consumption 2003 2010 in a macroeconomic context in Hungary and Germany. The Cobb-Douglas type of production function could be justified empirically, while originating from the general CES (Constant Elasticity of Substitution) production function. Furthermore, as a policy implication, the results suggest that a solution for the for the reduction of anthropogenic $\mathrm{CO} 2$ driven by the combustion of fossil fuels presupposes technological innovation to reach emission reduction targets. Other measures, such as increasing the fossil fuel price by levying taxes, would consequently lead to an undesirable GDP decline.
\end{abstract}

Keywords: production function, environmental pollution, transport emission, fossil fuels

\section{Introduction}

The neoclassical theory of economic growth and the development of constant elasticity substitution production functions in the $20^{\text {th }}$ century are closely connected. Solow's pioneering contribution (Solow, 1956) did not only create a new dynamic macroeconomic theory, but a new type of aggregate production functions was created. Arrow et al. (Arrow et. al., 1961), de Brown and Canin (de Brown et. al., 1963) continued to develop the theory of constant elasticity of substitution production functions. "During the 1970s, many economists tried to generalize the CES function to allow variations of the elasticity of substitution. These attempts showed such generalization is possible under very limited circumstances. Aside from such generalizing attempts, the CES function (Constant Elasticity of Substitution) obtained large attention after the invention of the taste-for-variety model: Spence (Spence, 1976) for the continuum variety case and Avinash and Stiglitz (Avinash, Stiglitz, 1977) for the discrete variety case."(Saito, 2011) The concept of production function in economics is interpreted as the transformation of production factors (e.g. labour, capital goods, fossil fuels, land, and air) to other goods (emissions). In essence the "production decision" is the choice of production factors and the amount of outputs. The idealized assumption of production theory is that of the company as a unit of economy making rational decisions. This presupposed that every company possesses all available information and strives to the maximum achievable profit (Kerepesi, Romvari, 1993). "CGE models (Computable General Equilibrium) are now extensively used in studies of the economy-energy-environment nexus at the national (Bergman, 1988; Conrad, Schröder, 1993; Beauséjour et. al, 1995; Lee, Roland-Holst, 1997; Goulder, 1998; Conrad, 1999) and regional levels (Despotakis, Fischer, 1988; Li, Rose, 1995). The popularity of CGEs in this context reflects their multi-sectoral nature combined with their fully specified supply-side, facilitating the analysis of economic, energy and environmental policies." (Allan et.al., 2007) Based on the introduced theoretical background, this article aims to analyse the profit-oriented economic actors especially focusing on their transport related fossil fuel consumption in Hungary and 
Germany. Further on authors show Cobb-Douglas Production Function (derived from CES production function) as a basic of CGE model.

\section{Methodology}

Cobb-Douglas production functions are widely used in consumption and production theory. Cobb and Douglas studied the contribution of each resource to the economic performance of the economic segments of the national economy (Cobb, Douglas, 1928; Maeda, 2010). In the below described model below described it is assumed that the economy is closed, and the input parameters for the produced output are capital, labour and fossil energy. The energy sources are imported. The economy is considered closed except for the energy sources (that is, export and import processes are excluded) and externalities were not taken into account. The usage of fossil fuel generates carbon dioxide emissions (Szendro, Torok, 2014; Shiwale et. al., 2014). Without the technological development, the efficiency of energy conversion for internal combustion, engines are constant so fossil energy consumption and carbon dioxide emission rates are linked (Vass, Német, 2013;Domanovszky, 2014). In this model fossil fuel consumptions were considered as a parameter of production.

Figure 1 illustrates the conceptual approach of deriving, the simplified Cobb-Douglas production function from the CES production function. Further on the Cobb-Douglas production function is used. Following a formal deduction, such functions will be estimated using time series data from two European countries.

General form of Constant Elasticity of Substitution (CES) Production Function:

$$
F\left(X_{i}\right)=\left(\sum_{i=1}^{m} a_{i} \cdot X_{i}^{\ominus}\right)^{\frac{1}{\Theta}}
$$

In two-factor case the form is simplified:

$$
F\left(X_{1}, X_{2}\right)=\left(a_{1} X_{1}^{\theta}+a_{2} X_{2}^{\theta}\right)^{\frac{1}{\theta}},
$$

To determine $a_{i}$ and $\theta$ the equation system should be calibrated
If $\theta=0$
if $\theta=1$
if $\theta=$ inf
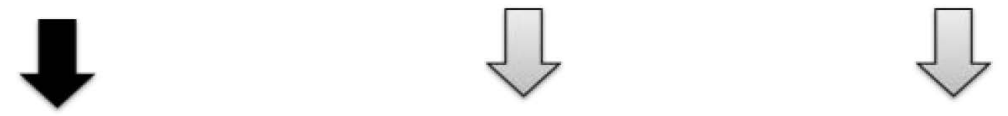

Simplified to

Cobb-Douglas Prod. Func.

$F\left(X_{1}, X_{2}\right)=X_{1}^{a_{2}} \cdot X_{2}{ }^{\left(1-a_{2}\right.}$

Simplified to:

Linear Prod. Func.
Simplified to:

Leontief Prod. Func.

$$
F\left(X_{1}, X_{2}\right)=\left(a_{1} \cdot X_{1}+\left(1-a_{1}\right) \cdot X_{2}\right) \quad F\left(X_{1}, X_{2}\right)=\min \left(a_{1} \cdot X_{1} ;\left(1-a_{1}\right) \cdot X_{2}\right)
$$

Figure 1. Visualisation of the model workflow (source: own representation)

The variables of the analysis and respective data sources are presented below. The time horizon of the analysis is 2003 through 2010. Despite of the on-going technological changes, in the investigated period, no significant technological changes were found, therefore production function is considered constant:

- Y: GDP [Billion HUF ${ }^{1} /$ year] - source: Eurostat

- Q: number of consumed consumer basket [piece $2 /$ year] - The World Factbook (ISSN 1553-8133)

\footnotetext{
${ }^{1}$ HUF: currency of Hungary

${ }^{2}$ The consumer basket is a set of products that the population consume in one year. These are products and services purchased from the market. Partly methodological, partly for technical reasons, certain purchases for (property) are not included. In our model, the population is assumed proportional to the number of product units.
} 
- $\quad$ p: price of consumer basket [HUF/piece] - algebraically calculated

- $\mathrm{F}_{\mathrm{c}}$ : Consumed fossil fuel [million litre/year] - source: Trading Economics http://www.tradingeconomics.com/

- $\mathrm{P}_{\mathrm{f}}$ : Price of fossil fuel [HUF/litre/year] source: The Automobile Association Limited http://www.theaa.com/

- $\quad \mathrm{K}:$ Number of companies [piece/year] - required to composite goods; source: Eurostat

- L: Number of employees [capita/year] - required to composite goods; source: Eurostat

- $r$ : Estimated unit cost of capital investment, assuming a maximum investment readiness [HUF/company/year] - required to composite goods; source: Economy Watch (http://www.economywatch.com/)

- w: yearly gross wage [HUF/capita/year] - required to composite goods; source: EuroMonitor (www.euromonitor.com)

- $\quad \beta$ : price of composite goods [HUF/piece] - algebraically calculated

- R: composite goods [piece] - algebraically calculated

- $\quad \Psi$ : Cobb Douglas parameter - algebraically calculated

- $\rho$ : technological parameter, $\rho=\frac{1}{(1-\sigma)}$, where $\sigma$ is the parameter of constant elasticity

Let $F$ be the production function (assuming a constant elasticity of substitution - CES), in general:

$\mathrm{Q}=F\left(\mathrm{~K}, \mathrm{~L}, \mathrm{~F}_{\mathrm{c}}\right)$

In other words, the output (Q) will change according to the used amount of capital (K), labour (L), and fossil fuels $\left(\mathrm{F}_{\mathrm{c}}\right)$. The decision problem of economic actors is described by a nested binary model in order to be able to use simplified tools of mathematics. Capital (K) and labour (L) are combined in a composite product $(\mathrm{R})$. Then the CES production function can be rewritten as (2):

$$
F\left(\mathrm{~K}, \mathrm{~L}, \mathrm{~F}_{\mathrm{c}}\right)=G\left(\mathrm{R}, \mathrm{F}_{\mathrm{c}}\right)
$$

Let $G$ and $H$ be production functions with constant elasticity of substitution (3) (4):

$$
G\left(\mathrm{R}, \mathrm{F}_{\mathrm{c}}\right)=\left(\Psi \cdot \mathrm{R}^{\rho}+(1-\Psi) \mathrm{F}_{\mathrm{c}}^{\rho}\right)^{1 / \rho}
$$

where

$\rho$ is the elasticity rate of fossil fuels $\left(\mathrm{F}_{\mathrm{c}}\right)$ and composite product $(\mathrm{R})$

$R=H(K, L)=\left(b_{1} K^{\theta}+b_{2} L^{\theta}\right)^{\frac{1}{\theta}}$

where

$\theta$ is the elasticity rate of capital $(\mathrm{K})$, labour $(\mathrm{L})$

$\mathrm{b}_{1}, \mathrm{~b}_{2}$ are the parameters

Then CES production function as an embedded binary production function will be as below (5):

$\mathrm{F}(\mathrm{K}, \mathrm{L}, \mathrm{F})=\left(\psi\left\{\left(\mathrm{b}_{1} \mathrm{~K}^{\theta}+\mathrm{b}_{2} \mathrm{~L}^{\theta}\right)^{\frac{1}{\theta}}\right\}^{\rho}+(1-\psi) \mathrm{F}_{\mathrm{c}}{ }^{\rho}\right)^{\frac{1}{\rho}}$

\section{Calibration of production function}

Taking into account equations (1) - (5) and the related assumptions of constant elasticity of substitution production function, the model calibration can be done according to the below presented two equations. So the coefficient and exponent parameters of the production functions with constant elasticity of substitution can be determined based on (6), (7):

$\psi \cdot\left(\frac{\mathrm{F}_{\mathrm{c}}}{\mathrm{Q}}\right)^{\rho}=\frac{\mathrm{P}_{\mathrm{f}} \mathrm{F}_{\mathrm{c}}}{\mathrm{Y}}$

$(1-\psi) \cdot\left(\frac{\mathrm{R}}{\mathrm{Q}}\right)^{\rho}=\frac{\mathrm{R} \cdot \mathrm{p}}{\mathrm{Y}}$

Equation (6) and (7) describes the connection between the prices and the volumes of output, and the used resources (composite goods and fossil energy). The correctness of the applied equations can be accepted if general form of CES function can be derived from them: 
$\psi \cdot\left(\frac{\mathrm{F}_{\mathrm{c}}}{\mathrm{Q}}\right)^{\rho}=\frac{\mathrm{P}_{\mathrm{f}} \cdot \mathrm{F}_{\mathrm{c}}}{\mathrm{Y}}$

$\psi \cdot\left(\frac{\mathrm{F}_{\mathrm{c}}}{\mathrm{Q}}\right)^{\rho}=\frac{\mathrm{F}_{\mathrm{c}} \cdot \mathrm{P}_{\mathrm{f}}}{\mathrm{Q} * \mathrm{p}}$

$\psi \cdot\left(\frac{F_{c}}{Q}\right)^{\rho-1}=\frac{P_{f}}{p}$

$\psi=\left(\frac{\mathrm{F}_{\mathrm{c}}}{\mathrm{Q}}\right)^{1-\rho} \frac{\mathrm{P}_{\mathrm{f}}}{\mathrm{p}}$

$\left(\frac{\mathrm{F}_{\mathrm{c}}}{\mathrm{Q}}\right)^{1-\rho}=\mathrm{p} \frac{\psi}{\mathrm{P}_{\mathrm{f}}}$

$\frac{F_{c}}{Q}=p^{\frac{1}{1-\rho}} \cdot\left(\frac{\psi}{P_{f}}\right)^{\frac{1}{1-\rho}}$

Finally, equation (13) is the general form of CES production function (Temple, 2012):

$\frac{X_{i}}{Y}=p^{\frac{1}{1-\rho}} \cdot\left(\frac{\beta_{i}}{w_{i}}\right)^{\frac{1}{1-\rho}}$

Hence the calibration equations can be accepted.

\section{Results}

The calibration process was carried out for every year and got the following results (Table 1) for Hungary and Germany as well:

Table 1.Results of calibration

\begin{tabular}{|r|r|r|r|r|}
\hline \multirow{2}{*}{ Country } & \multicolumn{2}{|c|}{ Hungary } & \multicolumn{2}{c|}{ Germany } \\
\hline \multirow{2}{*}{ Year } & $\begin{array}{l}\text { Cobb Douglas } \\
\text { parameter }(\psi)\end{array}$ & $\begin{array}{l}\text { Techno-logical } \\
\text { parameter }(\rho)\end{array}$ & $\begin{array}{l}\text { Cobb Douglas } \\
\text { parameter }(\psi)\end{array}$ & $\begin{array}{r}\text { Technological } \\
\text { parameter }(\rho)\end{array}$ \\
\cline { 2 - 5 } & $\{-\}$ & $\{-\}$ & $\{-\}$ & $\{-\}$ \\
\hline 2003 & .0350 & -.0014 & .0130 & .0008 \\
\hline 2004 & .0322 & .0006 & .0140 & -.0007 \\
\hline 2005 & .0332 & .0026 & .0142 & .0005 \\
\hline 2006 & .0373 & .0000 & .0169 & -.0003 \\
\hline 2007 & .0342 & -.0018 & .0153 & -.0004 \\
\hline 2008 & .0338 & -.0020 & .0117 & -.0011 \\
\hline 2009 & .0321 & -.0015 & .0150 & -.0003 \\
\hline 2010 & .0329 & -.0003 & .0173 & -.0002 \\
\hline
\end{tabular}

(source: own results)

As it can be seen - according to the estimation that has been done - the constant elasticity substitution production function $\mathrm{F}(\rho)$ parameter value is varying close to zero, in case of both Germany and Hungary. The same results were found in Japan for fossil fuel consumption modelling (Maeda, 2010) and for $\mathrm{SO}_{2}$ emission in China (Xu, Masui, 2008). The Cobb-Douglas production function in this case is by definition:

$F(K, L, F)=\left\{\left(b_{1} K^{\theta}+b_{2} L^{\theta}\right)^{\frac{1}{\theta}}\right\}^{\psi} \cdot F_{c}^{(1-\psi)}$

where $\psi \in\{0,1\}$ is known to be the share of consumption of $\mathrm{R}$ (as composite goods, so that $1-\psi$ is of $\mathrm{F}_{\mathrm{c}}$ ). From (15) - if $\mathrm{F}$ is a production function - then the marginal production of $\mathrm{R}$ and $\mathrm{F}_{\mathrm{c}}$ is (16) and (17):

$\frac{\partial \mathrm{F}}{\partial \mathrm{R}}=\psi \cdot\left(\frac{\mathrm{F}_{\mathrm{c}}}{\mathrm{R}}\right)^{1-\psi}$

$\frac{\partial \mathrm{F}}{\partial \mathrm{F}_{\mathrm{c}}}=1-\psi \cdot\left(\frac{\mathrm{F}_{\mathrm{c}}}{\mathrm{R}}\right)^{-\psi}$ 
after that ratio of marginal production (RMP) is algebraically calculated (18):

$\mathrm{RMP}=\frac{\partial \mathrm{F} / \partial \mathrm{R}}{\partial \mathrm{F} / \partial \mathrm{F}_{\mathrm{c}}}=\frac{\psi}{1-\psi} \cdot \frac{\mathrm{F}_{\mathrm{c}}}{\mathrm{R}}$

Since the relative change of a function is given by the derivative of its logarithm value (18) one obtains:

$\sigma=\frac{\mathrm{d} \cdot \ln (\mathrm{RMP})}{\mathrm{d}\left(\mathrm{F}_{\mathrm{c}} / \mathrm{R}\right)}=\frac{1}{\mathrm{~F}_{\mathrm{c}} / \mathrm{R}}$

Therefore the consumption share is fixed and so $\sigma=1$. This yields to the previously known conclusion that the CES function must converge to the Cobb-Douglas as $\rho \rightarrow 0$ (Saunders, 2008). As expected, the pparameteralues are varying close to zero. This suggested to use the Cobb-Douglas type in the following (Wei, 2006), (van der Werf, 2007) in combination with the two estimated parameters.

\section{Analysis and discussion}

The resulting function is:

$\mathrm{Q}=\mathrm{R}^{\psi} \cdot \mathrm{F}_{\mathrm{c}}^{(1-\psi)}$

$\mathrm{Y}=\mathrm{F}_{\mathrm{C}} \cdot\left(\mathrm{R}^{\psi} \cdot \mathrm{F}_{\mathrm{c}}{ }^{-\psi}-\mathrm{P}_{\mathrm{f}}\right)$

Figure 2 ( $a$ and $b$ ) visualises the data collected for the two cases investigated based on (21):

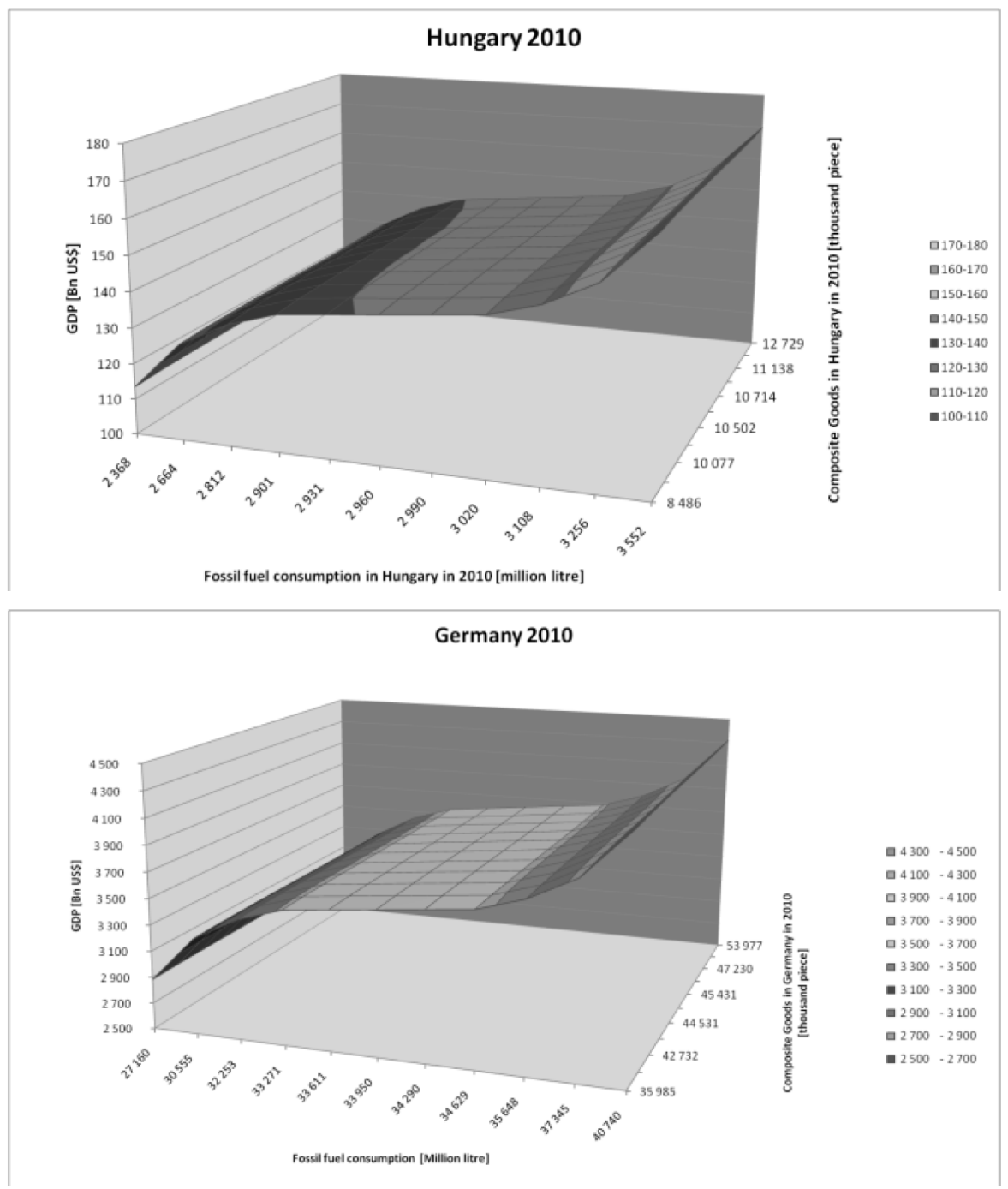

Figure $2(a$ and $b$ ). Visualisation of Cobb-Douglas production function in case of Hungary and in case of Germany (source: own representation) 
Figure 3 shows that the fossil fuel used for transport purposes has a strictly increasing marginal production cost curve. That means, if the production increasing then the unit cost is increasing, it is more costly to produce goods. With other words, increasing the fuel price by imposing taxes in order to increase fuel price to reach emission targets will hurt the economy.

\section{Investigation of fossil fuel consumption based production function} in Hungary and in Germany in 2010

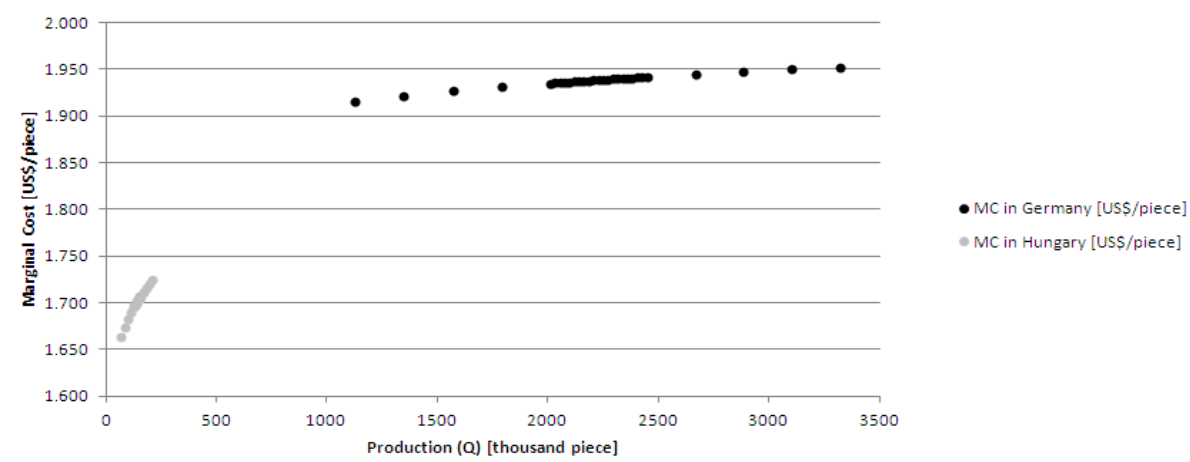

Figure 3. Investigation of fossil fuel consumption based on production function in 2010 (source: own representation)

In consequence it can be stated that the obvious solution to reach emission reduction target could be technological innovation to avoid the undesirable trends of GDP decline. It has to be taken into account that technological innovations and R\&D activities have their own costs. However, only the technological development can complete the emissions reduction without harming the economy. Accordingly, the common objectives to reduce the environmental pollution (Torok, 2014, Mitsakis, 2014), in particular greenhouse gas emissions, will depend on the substitution of composite goods (that contains labour work and investment) and fossil fuels. Further statistical analysis indicates that the CobbDouglas coefficients have not changed significantly in this case.

\section{Acknowledgement}

The authors are grateful to the support of Bólyai János Research fellowship of HAS (Hungarian Academy of Science).

\section{References}

1. Allan G., Hanley N., McGregor P., Swales K., Turner K. (2007): The impact of increased efficiency in the industrial use of energy: A computable general equilibrium analysis for the United Kingdom, Energy Economics, 29, p. 779-798.

2. Arrow, K. J., Chenery, H. B., Minhas, B. S. and Solow, R. M. (1961), Capital-Labor Substitution and Economic Efficiency, Review of Economics and Statistics 43, p. 225-250.

3. Avinash K., Stiglitz E. (1977): Monopolistic competition and optimum product diversity, American Economic Review 67 (3), p. 297-308.

4. Beauséjour, L., Lenjosek, G., Smart, M., (1995): A CGE approach to modelling carbon dioxide emissions control in Canada and the US. The World Economy 18, p. 457-489.

5. Bergman, L., (1988): Energy policy modelling: a survey of general equilibrium approaches. Journal of Policy Modelling 10, p. 377-399.

6. Cobb, C. W., Douglas, P. H. (1928): A Theory of Production. American Economic, Review Supplement 18: p. 139-165.

7. Conrad, K., (1999): Computable general equilibrium models for environmental economics and policy analysis. In: van den Bergh, J.C.J.M. (Ed.), Handbook of Environmental and Resource Economics. Edward Elgar Publishing Ltd, Cheltenham.

8. Conrad, K., Schröder, M., (1993): Choosing environmental policy instruments using general equilibrium models. Journal of Policy Modelling 15, p. 521-543. 
9. de Brown, M. and de Carni, J. S. (1963), Technological Change and the Distribution of Income, International Economic Review 3, p. 289-309.

10. Despotakis, K.A., Fisher, A.C., (1988): Energy in a regional economy: a computable general equilibrium model for California. Journal of Environmental Economics and Management 15, p.313330 .

11. Domanovszky, H. (2014). Gas propulsion or e-mobility is the solution on the way of clean and carbon free road transportation? Periodica Polytechnika Transportation Engineering, 42(1), 63-72.

12. Goulder, L.H., (1998): Effects of carbon taxes in an economy with prior tax distortions: an intertemporal general equilibrium analysis. Journal of Environmental Economics and Management 29, p271-297.

13. Kerepesi K, Romvári E. (1993): Economics for Engineers [in Hungarian: Közgazdaságtan mérnököknek], Müegyetemi Kiadó, Budapest, p.471.

14. Lee, H., Roland-Holst, D.W., (1997): Trade and the environment. In: Francois, J.F., Reihert, K.A. (Eds.), Applied Methods for Trade Analysis: A Handbook. Cambridge University Press, Cambridge.

15. Li, P., Rose, A., (1995): Global warming policy and the Pennsylvania economy: a computable general equilibrium analysis. Economic Systems Research, 7, p.151-171.

16. Maeda A., (2010): Estimating the Impact of GHG Target-Setting on the Macroeconomy, Kyoto Sustainability Initiative, Kyoto University

17. Mitsakis, E., Papanikolaou, A., Ayfadopoulou, G., Salanova, J., Doll, C., Giannopoulos, G., \& Zerefos, C. (2014). An integrated framework for linking climate change impacts to emergency adaptation strategies for transport networks. European Transport Research Review, 6(2), 103-111.

18. Saito T. (2011): The Algebra of Convergence from CES to Cobb-Douglas and Leontief, Lecture Notes State University of New York at Buffalo.

19. Saunders, H. D. (2008): Fuel conserving (and using) production functions, Energy Economics 30, p.2184-2235.

20. Siwale, L., Kristóf, L., Adam, T., Bereczky, A., Penninger, A., Mbarawa, M., \& Andrei, K. (2013). Performance Characteristics of n-Butanol-Diesel Fuel Blend Fired in a Turbo-Charged Compression Ignition Engine. Journal of Power and Energy Engineering, 1(05), p.77-83.

21. Solow, R. (1956), A Contribution to the Theory of Economic Growth, Quarterly. Journal of Economics 70, p.65-94.

22. Spence, M. (1976): Product selection, fixed costs, and monopolistic competition, Review of Economic Studies 43 (2), p.217-35.

23. Szendrö, G., \& Török, Á. (2014). Theoretical investigation of environmental development pathways in the road transport sector in the European Region. Transport, 29(1), p.12-17.

24. Temple J. (2012): The calibration of CES production functions, Journal of Macroeconomics 34 p. 294-303.

25. Torok A. (2014): Environmental Comparism Of Road And Railway Transport: A Case Study In Hungary, Inetrnational Journal for Traffic and Transport Engineering, 4(2):210-219 doi: 10.7708/ijtte.2014.4(2).07

26. van der Werf E. (2007): Production Functions for Climate Policy Modelling: An Empirical Analysis, Kiel Working Paper No. 1316, Research Paper, Kiel Institute for the World Economy, Duesternbrooker Weg 120, 24105 Kiel (Germany), p.31.

27. Vass, S., Németh, H. (2013). Sensitivity analysis of instantaneous fuel injection rate determination for detailed Diesel combustion models. Periodica Polytechnika Transportation Engineering, 41(1), p.77-85.

28. Wei T. (2006): Impact of energy efficiency gains on output and energy use with Cobb-Douglas production function, Energy Policy, 35, p.2023-2030.

29. Xu Y, Masui T (2008): Local air pollutant emission reduction and ancillary carbon benefits of SO2 control policies: Application of AIM/CGE model to China, European Journal of Operational Research 198, p. 315-325. 